\title{
Developing Mathematics Problem Based on PISA Level of Space and Shape Content to Measure Student's Mathematics Problem Solving Ability
}

\author{
Riski Sahrida Nasution*, Kms. Muhammad Amin Fauzi, Edi Syahputra \\ State University of Medan, Jalan William Iskandar Pasar V, Medan, Indonesia \\ *Corresponding author: riskisahrida28@gmail.com
}

Received August 18, 2019; Revised September 21, 2019; Accepted October 05, 2019

\begin{abstract}
This research aims to produce mathematics problems based on the PISA level content of Space and Shape with valid and practical procedures for developing problems and measure students' mathematics Problemsolving ability. The method used in this research is the development research method. This research consists of two stages, namely preliminary and formative evaluation stages which include self-evaluation, expert reviews, one-toone, small groups, and field tests. Data collection techniques are based on walk-throughs, documents, tests, and questionnaires. After going through the one-to-one, small group, and descriptive validation stages, the questions were tested in the field test stage in class VIII of SMP Negeri 1 Padangsidimpuan. The results show the average value of mathematics problem-solving ability is 56.07 and it is categorized as Enough mathematics problem-solving ability, although there are still students who categorized in low. From these results, it can be said that developed PISA level questions are categorized as valid and practical criteria and have a potential effect on students' mathematics problem-solving abilities.
\end{abstract}

Keywords: development research, mathematics problem solving ability, Pisa model mathematics problem, space and shape

Cite This Article: Riski Sahrida Nasution, Kms. Muhammad Amin Fauzi, and Edi Syahputra, "Developing Mathematics Problem Based on PISA Level of Space and Shape Content to Measure Student's Mathematics Problem Solving Ability.” American Journal of Educational Research, vol. 7, no. 10 (2019): 660-669. doi: 10.12691/education-7-10-1.

\section{Introduction}

Mathematics is a universal science that underlies the development of modern technology, has an important role in various disciplines and develops human thought. The rapid information and communication technology today is based on the development of mathematics in number theory, algebra, analysis, probability theory, and discrete mathematics. However, in reality, Indonesia only has a fairly low mathematical ability. Many factors affect the low mathematical ability in Indonesia, namely teachers lack mastery in understanding the 2013 curriculum, students are less trained in working on problems with the characteristics of the Program for International Assessment (PISA), students are lack understanding in solving contextual problems. The 2013 curriculum requires students to be more independent and students can solve math problems related to daily life. The development of mathematics problems in this globalization era refers to the PISA problem. Indonesia in dealing with PISA mathematics problems is still experiencing difficulties. The involvement of PISA is to see the extent to which programs in Indonesia are developing compared to other countries. Also, exercises like PISA problems can improve students' reasoning ability.

PISA is an international standard study organized by OECD (Organization for Economic Cooperation and Development) which studies student's mathematical literacy ability [1]. According to [2], mathematical literacy is the ability of individuals to formulate, apply, and interpret mathematics in various contexts. It is including mathematical reasoning and using mathematical concepts, procedures, facts and mathematical tools to describe, explain and predict phenomena/ events. PISA provides important information about student skills at the junior high school level, which is about 15 years old students in using mathematics in daily life [3]. PISA uses an innovative literacy approach, a learning concept that is related to students' ability to apply knowledge and skills in key subjects accompanied by the ability to study, reason, communicate effectively and solve and interpret problems in various situations [4]. PISA is designed to find out whether students can use their mathematical potential in real life in society through a contextual mathematical learning concept [5]. Factors that influence the successfulness of research with PISA level problems are: (a) Students have not been able to adjust PISA problems, because adjusting PISA questions requires much time and 
effort. This statement is supported by [6] which states that one of the factors causing the low mathematical literacy ability of Indonesian students is not being trained in solving problems with characteristics of PISA problems; (b) The ability of students to construct contextual problems into mathematical contexts is still considered to below. This is very influential because the PISA problem starts with a contextual and real problem. PISA does not only make students learn about mathematics in real life but also practice students' mathematical literacy ability according to their age. Therefore, one of the efforts that can be done is to encourage teachers and students to plan a PISA- based learning and design a learning evaluation which is by the characteristics of PISA [7]. Besides, teachers are also required to be able to design the problem using a context which is close to the life of their students [8].

Various researches on the development of mathematical PISA-like problems for High School students with various focus both on content and ability have been conducted. For example, [9] Pengembangan Soal Matematika Model PISA Berbasis Online; [10] Pengembangan Soal Model PISA Untuk Mengetahui Profil Literasi Matematis Siswa SMA; [11] also wrote a journal entitled Pengembangan Soal Matematika Model PISA Untuk Program Pengayaan Kelas VII SMP; [12] developed the PISA problem to measure students' mathematical communication ability; [13] developed level 6 PISA problem for junior high school; [14] developed the PISA-like mathematics task with the context of Indonesian natural and cultural heritage. This shows that many parties are interested and consider that the development of problem-based on PISA level is very necessary. Based on the mathematical framework of PISA 2015, the mathematical content in PISA consists of changes and relationships, spaces and shapes, numbers, and uncertainties and data [15]. Various contents are more specific in it, such as geometry, number patterns, algebra, probabilities and uncertainties, and data. Based on the survey Program for International Students Assessment (PISA) 2000/2001, it shows that students are weak in geometry, especially in understanding space and shape [16]. Likewise, researchers note that students experience difficulties and show poor performance in learning geometry. Usiskin stated that many students failed to understand key concepts in geometry [17]. Stated that many of the weaknesses in Indonesian students' mathematical abilities are revealed in the results of the PISA study [18]. In general, students' weaknesses are not yet able to develop their reasoning ability, do not have the habit of reading while thinking and working in order to understand essential and strategic information in solving problems, and still tend to "accept" information and then forget it, so mathematics subjects have not been able to become a "school of thinking" for students. According to [19], the factors that cause students' mistakes in solving PISA problems are low students' reasoning and creativity in solving real context problems and manipulating them into mathematical form. Mathematical reasoning is one of the basic abilities needed in mathematical literacy [20].

Based on the results achieved by Indonesia in PISA, it shows that students in Indonesia are still ranked 63 out of 72 countries for mathematics literacy [21]. One of the causes of the low ability of mathematics literacy is the lack of availability of learning tools that can support the improvement of mathematical literacy ability, including the use of learning instruments or student activity sheets that do not present assignments to improve their literacy ability [22]. Given the importance of problem-solving, so the NCTM [23] states that problem-solving is a major focus in mathematics learning. Problem-solving skills are the ability that students learn from mathematics, so that practice is part of solving math problems. The more students are experienced in solving problems, the better the problem-solving skills it has. According to Mayer [24] problem solving as cognitive processing directed at transforming a given situation into a goal situation when no obvious method of Solution is available. Means resolution as cognitive processing is geared towards changing certain situations into a destination situation when no obvious solution method is available.

Model learning of mathematics at this time affected the more conventional view that the mathematical tools at its disposal. This view encourages teachers are inclined to say concepts/theorems and how to use them. Teachers tend to transfer knowledge to students and students' minds to accept passively and uncritically. This attitude often gives the deadlock think students where students can use the formula but do not know where it came from that formula and why the formula was used, in other words, students can only use the formula as a tool to answer questions and instead finding solutions and solving of problems that arise [25]. According to [26] The purpose of problem-solving is given to students is: (a) It can elicit curiosity and motivation, cultivating the nature of creativity; (b) In addition to having the knowledge and skills (counting, etc.) is required the ability to skillfully read and make correct statements; (c) may give rise to genuine, new, distinctive, and varied answers, and may add new knowledge or can improve the application of science that has been acquired; (d) Inviting students to have problem-solving procedures, able to make analysts the troubleshooting indicators used by PISA 2003 [27] are (1) Understand the Problem, (2) Characteristic the Problem, (3) Represent the Problem, (4) Solve the Problem, (5) Reflect on the Solution, (6) Communicate the Problem Solution. Thus, from these six indicators, researchers will limit the indicators to be used 1) Understand the Problem, 2) Represent the Problem, 3) Solve the Problem.

In 2012 PISA, Indonesia was only slightly better than Peru which was ranked lowest. The average mathematics score of Indonesian children was 375. Indonesia ranks 64 out of 65 countries with an average score of 375 , while the average international score is 500 [28]. This shows the ability of Indonesian students to solve problems that demand the ability to study, give reasons, communicate effectively, and to solve and interpret problems in various situations is still low. Regarding [29], to help teachers to implement problems based on the PISA level is to provide students with bank problems of the PISA level. From the description above it can be concluded that problems based on PISA level do not only require the ability to apply concepts but rather how they can be applied in various situations and students' reasoning ability, solve problems and argue about how they can be 
solved. Based on some of the descriptions above, this research was conducted in SMP VIII to know and recognize students' mathematics problem-solving ability from the results of solving the problem based on PISA level on Space and Shape.

The results of this research are expected to provide information to the school about the ability of students in the discipline of mathematics so that it can help to improve student abilities and the quality of mathematics. This research was using a problem based on the PISA level on Space and Shape topic because it consists of the mathematics problem solving of students at the junior high school level. An interesting problem to be examined in this research is the Developing of Mathematics Problem Based on PISA Level of Space and Shape to Measure Students' Mathematics Problem Solving Ability in SMP Negeri 1 Padangsidimpuan.

\section{Research Methodology}

This research was conducted at SMP Negeri 1 Padangsidimpuan in class VIII in the second semester of the academic year 2018/2019. The type of research is a research \& development (Design Research). The development model used is the Tessmer development model type of formative evaluation [30]. In the formative evaluation stage following the developing flow, the steps included self-evaluation, expert reviews, one-to-one, small group, and field test [31]. The preliminary stage is the preparation stage that the researcher will undertake to determine the place and subject of the research by contacting the principal and teacher to arrange a schedule and procedure for collaboration. The next stage is prototyping were the products that have been made or designed to be evaluated. The design results of the first prototype were developed based on self-evaluation which given to experts (Expert Review), students ( One-to-one ) and small groups in parallel. At this stage comments or suggestions as well as the results of trials on the first prototype serve as the basis for revising the design of the first prototype. The revised results tested on research subjects as a field test. Trials at this stage of the product were tried out to students of class VIII of SMP Negeri 1 Padangsidimpuan who were subjected to field trials. Furthermore, the data obtained from the field test was analyzed through reliability, difficulty level, and distinguishing features.

The data collection techniques used are walkthrough, documents, and tests of PISA problems on space and shape to measure students' problem-solving ability. Data analysis techniques used in the test instrument of mathematics problem-solving ability are the analysis of contents problems validity, analysis of students' questionnaires, reliability testing, difficulty level test, distinguishing power, and data analysis of mathematical reasoning ability.

Validity refers to the Measuring instrument against the mastery of the concept being measured so that it actually measures what should be measured. To calculate the validity of the test. [32] suggests a formula used to calculate validity, namely the correlation of product moments as follows:

$$
r_{x y}=\frac{N \sum_{i=1}^{N} X_{i} Y_{i}-\left(\sum_{i=1}^{N} X_{i}\right)\left(\sum_{i=1}^{N} Y_{i}\right)}{\sqrt{\left\{N \sum_{i=1}^{N} X_{i}^{2}-\left(\sum_{i=1}^{N} X_{i}\right)^{2}\right\}\left\{N \sum_{i=1}^{N} Y_{i}^{2}-\left(\sum_{i=1}^{N} Y_{i}\right)^{2}\right\}}}
$$

Description:

$N$ : Number of student taking the test

$X_{i}$ : Scores Earned on each item

$Y_{i}$ : Total scored of each item

$r_{x y}$ : Coefficient of validity test.

Next, to determine the validity of a test item, it is used to test $t=r_{x y} \sqrt{\frac{N-2}{1-\left(r_{x y}\right)^{2}}}$ with the criteria to be met is if $\mathrm{t}_{\text {hitung }}>\mathrm{t}_{\text {tabel }}$ with tabel $=\mathrm{t}(1-\alpha)(\mathrm{dk})$ for $\mathrm{dk}=\mathrm{N}-2$ and $\alpha$ (significant level) is selected 5\% The Instrument is valid, can the interpretation of the correlation coefficient used criteria according to [32] is as Table 1 follows:

Table 1. Interpretation Of Correlation Coefficient Product Moment

\begin{tabular}{lc}
\hline Interpretation of the correlation coefficient & Description \\
\hline $0,80 \leq r_{x y} \leq 1,00$ & Tests have very high \\
validity \\
$0,60 \leq r_{x y} \leq 0,80$ & Tests have high \\
validity \\
$0,40 \leq r_{x y} \leq 0,60$ & Tests have moderate \\
$0,20 \leq r_{x y} \leq 0,40$ & validity \\
$0,00 \leq r_{x y} \leq 0,20$ & Tests have low \\
validity \\
\end{tabular}

To interpret the validity price of each item, the price is consulted on the Critique Price table $r_{\text {tabel }}$ productmoment with $\alpha=0,05$. If $r_{\text {hitung }}>r_{\text {tabel }}$, The test is considered valid.

For the calculation of the test reliability, [33] suggests that the reliability coefficient of test form description (Essay test) can be used Alpha formula, as follows:

$$
r_{11}=\frac{n}{n-1}\left(1-\frac{\sum_{i=1}^{n} \delta_{i}^{2}}{\delta_{t}^{2}}\right)
$$

Description:

$r_{11}$ : Overall test reliability

$\sum \delta_{i}^{2}$ : Number of score variances of each problem

$\delta_{t}^{2}$ : Total Variance

$\mathrm{N}$ : Number of items in the test.

Table 2. Interpretation Of Test Reliability Coefficient

\begin{tabular}{ll}
\hline Size of coefficient $\mathbf{r}$ & Category \\
\hline $0,800 \leq r_{11} \leq 1,000$ & Very high \\
$0,600 \leq r_{11}<0,800$ & High \\
$0,400 \leq r_{11}<0,600$ & Enough \\
$0,200 \leq r_{11}<0,400$ & Low \\
$0,000 \leq r 11<0,200$ & Very Low \\
\hline
\end{tabular}


The index of this difficulty level is generally expressed in proportion to the magnitude of 0.00-1.00. The larger the index of the difficulty level gained from the count result, the easier it is. A question of having TK $=0.00$ means that no student is properly answered and if having $\mathrm{TK}=1.00$ means that the student is right. The formula below is used for description. The formula is like the following:

$$
T K=\frac{\text { Mean }}{\text { Maximum score of each problemal }}
$$

With

$$
\text { Mean }=\frac{\left(\begin{array}{l}
\text { Number of learners } \\
\text { per problemeserta didik tiapsoal }
\end{array}\right)}{\text { Number of students }} .
$$

Table 3. Difficulty Level Criteria

\begin{tabular}{|l|c|}
\hline Index & Difficulty Level \\
\hline $0,00-0,29$ & Difficult \\
\hline $0,30-0,69$ & Enough \\
\hline $0,70-1,00$ & Easy \\
\hline
\end{tabular}

The distinguishing Power Index of each item is usually also expressed in proportion. The differentiator Power Index ranges from-1.00 to +1.00 . The higher the differentiator's power, the stronger/better the problem. To know the differentiator about the description form is to use the following formula.

$$
D P=\frac{\bar{X}_{K A}-\bar{X}_{K B}}{\text { Maximum score Test }} .
$$

The criteria are as follows:

Table 4. Interpretation Of Distinctive Power Category

\begin{tabular}{ll}
\hline Power Differentiator & Category \\
\hline $\mathrm{Dp} \leq 0,00$ & Lowest \\
$0,00<\mathrm{Dp} \leq 0,20$ & Low \\
$0,20<\mathrm{Dp} \leq 0,40$ & Enough \\
$0,40<\mathrm{Dp} \leq 0,70$ & Good \\
$0,70<\mathrm{Dp} \leq 1,00$ & Excellent \\
\hline
\end{tabular}

The Data obtained from the results of the reasoning ability Test and the student response poll on the test are analyzed to know the skills of mathematics problem solving of the students, by comparing the average score students gained and the average score for each Mathematics problem-solving ability Indicators of the test results. Scores of mathematics problem-solving ability students are the number of scores students gained when completing mathematics problem-solving ability tests. The final value that the student acquired is:

$$
K B=\frac{T}{T_{t}} \times 100
$$

Description:

KB: Learning Submission

$\mathrm{T}$ : Number of scores earned by students

$\mathrm{T}_{\mathrm{t}}$ : Total Score Number

The capability Test Data is analyzed to determine the category of levels of students' mathematics problem-solving ability. The category of mathematics problem-solving

\begin{tabular}{|c|c|}
\hline Student Grades & $\begin{array}{l}\text { Levels of student mathematics problem-solving } \\
\text { ability }\end{array}$ \\
\hline $80<$ value $\leq 100$ & Excellent \\
\hline $60<$ value $\leq 80$ & Good \\
\hline $40<$ value $\leq 60$ & Enough \\
\hline $20<$ value $\leq 40$ & Low \\
\hline $0 \leq$ value $\leq 20$ & Lowest \\
\hline
\end{tabular}
ability of the student is determined as in the following table:

Table 5. Mathematics Problem Solving Ability Category

To determine the positive presence of students ' responses to the problem of PISA, student response data is analyzed in a quantitatively descriptive form of percentages and grouped for each indicator. The student response percentage is calculated using the formula [34].

Student response percentage $=\frac{A}{B} \times 100 \%$.

Description:

Positive The proportion of students who respond positively

B: Number of students who are respondents.

Interpretation of the average poll score on Table 6 using the modified Likert scale of [35].

Table 6. Student Response category in the learning activities

\begin{tabular}{ccc}
\hline No & Student response percentage (\%) & Category \\
\hline 1. & $81-100$ & Excellent \\
2. & $61-80$ & Good \\
3. & $41-60$ & Enough \\
4. & $21-40$ & Low \\
5. & $0-20$ & Lowest \\
\hline
\end{tabular}

At least $80 \%$ of many of the subjects studied gave a positive response to the materials that had been developed.

\section{Results and Discussion}

This research is development research, so the product of this research is a learning tool in the form of problembased on PISA level. The purpose of this development research is to describe: (1) the validity of developing mathematics problem based on PISA level in Shape and Space at class VII of SMP Negeri 1 Padangsidimpuan; (2) the practicality developing mathematics problem based on PISA level in Shape and Space at class VII of SMP Negeri 1 Padangsidimpuan; (3) procedure for developing mathematics problem based on PISA level in Shape and Space; (4) describe the measurement of students' problem solving ability at SMP Negeri 1 Padangsidimpuan through the problem based on PISA level in Shape and Space. Analysis of the data and research results obtained for each stage of the Tessmer development model are presented as follows.

\subsection{Description of the Preliminary Stage}

This stage begins with the collection of several references related to this research, namely research development, test instruments, and students' mathematics problem-solving ability. The next step is determining the 
place and subject of the research trial. The place of trial in this research was SMP Negeri 1 Padangsidimpuan. While the test subjects in this research were students of class VIII-3 of SMP Negeri 1 Padangsidimpuan. After determining the place and subject of the trial, observations were made aimed at identifying learning activities and students' mathematics problem-solving ability at SMP Negeri 1 Padangsidimpuan class VIII-3.

\subsection{Description of Self Evaluation Stages}

This stage has 4 activities, namely curriculum analysis, material analysis, student analysis, and design. Curriculum analysis was carried out to establish the basic problems needed in developing test instruments so that it can measure students' mathematics problem-solving abilities. The development of a problem based on PISA level in Space and Shape refers to the 2013 Curriculum. Student analysis focused on students of class VIII-3 as a test subject because the material was studied in class VIII. The average number of students in each class was 28 students. Based on observations and interviews with mathematics teachers, it can be seen that the mathematics knowledge of grade VIII-3 students was varied. There were less, medium and high abilities. This showed that there were different factors of interest for each student towards mathematics. In general, students' mathematics problemsolving ability has never been explored either by the teacher or other researchers. Material analysis is an activity to identify the main concepts that will be used in tests on grade VIII SMP.

Based on the curriculum analysis, it was found that the material to be used in the development of problem-based PISA levels in the Space and Shape which following the material in the 2013 curriculum was cubes and beams. After the material analysis activity is carried out the next step is to design problem based on PISA level in Space and Shape of high level thinking skills, including: test grids, test questions, answer sheets and assessment guidelines as consideration for the validator to check the validity of the content, construct and language of the mathematical problem solving ability test instrument. The test instrument grid is designed based on reasoning indicators for each question, the answer sheet is designed to contain steps for solving each problem to practice mathematical Problem Solving ability.

\subsubsection{Description of Prototyping Phase (Validation, Evaluation, and Revision)}

The purpose of this prototyping stage was to produce prototype II of the revised test instrument based on expert review and data obtained from one-to-one trials. Expert Review was used as a basis for revising and refining prototypes. The instrument validation was carried out by providing a validation sheet of test instruments, test questions, and answer sheets to the validator, which consisted of three mathematics lecturers from Universitas Negeri Medan and two mathematics teachers at SMP Negeri 1 Padangsidimpuan.

Suggested revisions from validator to the instrument which includes a test grid, test questions, test answer sheets, and student answer keys, can be seen in Table 7 below.

Comments and suggestions from the validator were used as consideration for revising the prototype of the test instrument to produce a second prototype.

\subsubsection{One to one}

In addition to the mathematical problem-solving ability test questions validated by experts, the test was also tested one to one on several students at SMP Negeri 1 Padangsidimpuan. These students were 3 non-subjects students who in high, medium, and low ability. The picture below is the answer of the first and second subjects with a high and medium ability on the answer sheet and can be seen that the answer is correct.

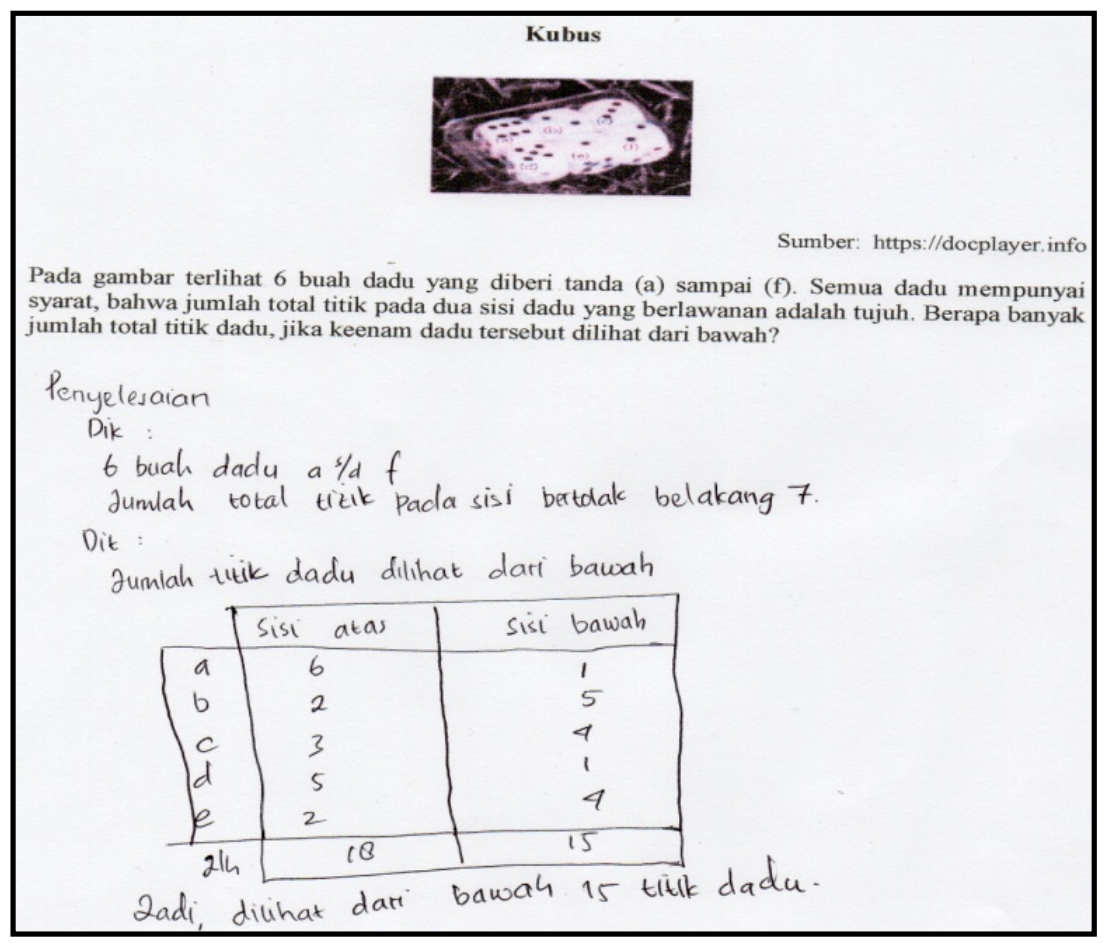

Figure 1. Problem and Answer Number 1 of the Pisa Model for Space and Shape 
Table 7. Suggestions for Revision by Validator

\begin{tabular}{|c|c|c|}
\hline Validator & Instrument & Revised Suggestions \\
\hline \multirow{3}{*}{ Validator 1} & \multirow{2}{*}{ - Test questions } & - Writing errors are noted \\
\hline & & - The picture in the problem is enlarged \\
\hline & - Answer key & - The answer to the cube problem is corrected to be clearer \\
\hline \multirow{7}{*}{ Validator 2} & - Test Grating & - Writing time allocation should be 2x40 minutes. \\
\hline & \multirow{4}{*}{ - Test Questions } & - Writing errors are noted \\
\hline & & - The source of the image is completed \\
\hline & & - Adjust the problem with the mathematical problem-solving indicator \\
\hline & & - Complete the problem with the description of several pictures. \\
\hline & - Scoring Guidelines & - Adjust the sound of the indicator \\
\hline & \multirow{3}{*}{ - Test Questions } & - Study errors are considered \\
\hline \multirow{3}{*}{ Validator 3} & & - Clarify the picture to make it clear the question of the problem is made \\
\hline & & - The sentence in the problem must match the information in the picture \\
\hline & Answer key & - Create a scoring stage so that researchers and others easily make an assessment \\
\hline \multirow{2}{*}{ Validator 4} & \multirow{2}{*}{ Test Questions } & - Improve writing in the problem \\
\hline & & - Make the test more interesting \\
\hline Validator 5 & Test Questions & - Writing errors are noted \\
\hline
\end{tabular}

From interviews with S1 and S2, they were able to explain that the number of points on the dice that appeared from below was 15 points. They were able to associate two-dimensional images with actual dice shapes (3 dimensions). This meant that both subjects were relating the problem to their real life. When interviewing, the researcher asked, "Bukankah yang Nampak pada Sisi Bawah Tidak Kelihatan Hanya Angka yang di Atas yang Kelihatan?" (Don't you see what appears on the underside are only the numbers above that appear). The answers to the two subjects were almost the same. They understood the shape of the dice in a real context.

The students' comments on completing the PISA questions in the one-to-one stage can be seen in Table 8 below.

\section{Small-Group}

In addition to the mathematical problem-solving ability test instrument, questions were validated by experts and tested on one to one the questions were also trialed by Small Group on several students of SMP Negeri 1 Padangsidimpuan. These students were 6 non-subject in high, medium, and low ability based on the learning outcomes known by a mathematics teacher.

The picture below is a question and answer sheet from one of the subjects in the small group.

Based on Figure 2 showed that student only wrote the formula without answering what the problem was meant. In the process of solving these problems, students were not careful enough so the answer was wrong.

Table 8. Feedback from Students One-to-One

\begin{tabular}{|c|c|c|}
\hline Student Subject & Comment & Suggestion \\
\hline S1 & - The instructions in the first problem are not clear. & - Add numbers and dice made 1 to 6 to make it clearer. \\
\hline $\mathrm{S} 2$ & $\begin{array}{l}\text { - The picture in the problem is clarified so that you can } \\
\text { understand more }\end{array}$ & - Because it's better to be printed, not photocopied. \\
\hline S3 & $\begin{array}{l}\text { - Most of the questions are understood but in the question } \\
\text { section No. } 4 \text { problem instruction is not clear }\end{array}$ & $\begin{array}{l}\text { - The sentence is better simplified so that it is better } \\
\text { understood }\end{array}$ \\
\hline
\end{tabular}

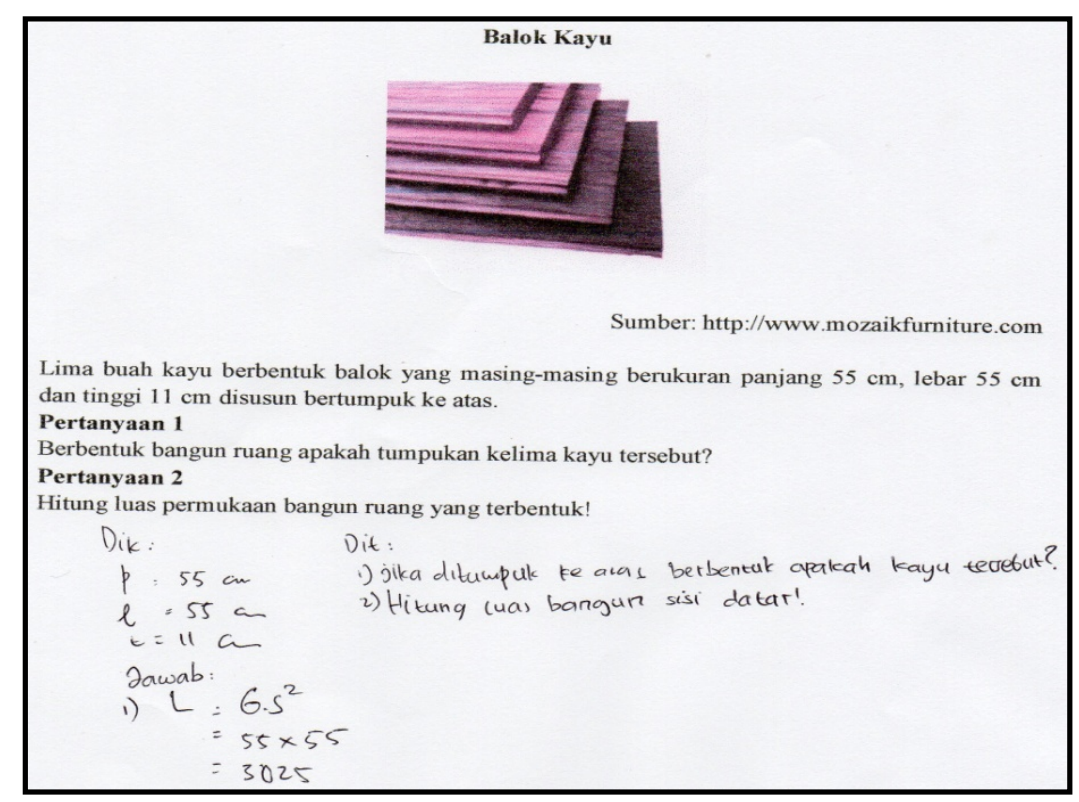

Figure 2. Problem and Answer Number 4 Pisa Model for Space and Shape 
Table 9. Comments and Suggestions from Small-Group Students

\begin{tabular}{|c|c|c|}
\hline Student Subject & Comment & Suggestion \\
\hline S1 & $\begin{array}{l}\text { - In question number } 4 \text { there is no picture so I have difficulty } \\
\text { determining the intended space }\end{array}$ & - Better to take a picture of the problem \\
\hline $\mathrm{S} 2$ & $\begin{array}{l}\text { - Problem number } 2 \text { is better to clarify the instructions, the picture is } \\
\text { also blurred }\end{array}$ & $\begin{array}{l}\text { - Preferably below the picture, an explanation is } \\
\text { made }\end{array}$ \\
\hline S3 & $\begin{array}{l}\text { - Problem number } 1 \text { which is seen from the lower or upper side of the } \\
\text { problem is still unclear }\end{array}$ & - More clearly visible sides of the back of the dice \\
\hline S4 & $\begin{array}{l}\text { - Problem number } 4 \mathrm{I} \text { had difficulty determining the intended space and } \\
\text { in question number } 5 \text { the volume of each picture was not made }\end{array}$ & $\begin{array}{l}\text { - The drawing should be made in question number } 4 \\
\text { and the volume of the image made below }\end{array}$ \\
\hline S5 & $\begin{array}{l}\text { - The problem is understood, but there are still wrong words in the } \\
\text { problem and the picture in the problem to make it clearer }\end{array}$ & - The sentence in the problem should be fixed \\
\hline S6 & $\begin{array}{l}\text { - Problem number } 5 \text {, the picture is more clarified and the volume of } \\
\text { each picture should be clarified }\end{array}$ & The volume should be made below the picture \\
\hline
\end{tabular}

\section{Field Test Stage}

The prototype which has been validated and revised (prototype II), was tested on the subject of research trials, namely students of class VIII-3 of SMP Negeri 1 Padangsidimpuan. The class contained 23 students, but at the time of the trial, there was one student who did not attend school. Tes activities carried out for $2 \times 40$ minutes. The results of the test answers obtained from the work of students of class VIII-3 of SMP Negeri 1 Padangsidimpuan were analyzed to measure or determine the level of mathematical problem-solving ability of students. Besides, based on the results of student work will also be analyzed the reliability of the developed test instruments, in this stage also revised the instruments that have been tested to produce an appropriate product.

\subsection{Analysis of Test Item Validation Test Results}

The validity of the questions was analyzed by using Pearson's product-moment correlation formula by correlating the score of the item items with the total score. The results of testing the test instrument for understanding comprehension are presented in Table 10 below.

Table 10. Validity of Item Reasoning Ability Tests

\begin{tabular}{ccc}
\hline Item & $\boldsymbol{r}_{\boldsymbol{x y}}$ & Interpretation \\
\hline 1. & 0,8671 & Signifikan/Valid \\
2. & 0,7688 & Signifikan/Valid \\
3. & 0,7891 & Signifikan/Valid \\
4. & 0,8525 & Signifikan/Valid \\
\hline
\end{tabular}

Table 10 is a research instrument testing of reasoning ability test for six essay questions with a significance level of $5 \%, d k=24$, obtained $t$ table $=2.0555$. If referring to the testing criteria, the test criteria are $t_{\text {count }}>t_{\text {tabel }}$, then the mathematical problem-solving ability test can be used or valid. Thus based on calculations performed by manual, excel, and SPSS 22, it is concluded that the problemsolving ability test can be used or valid.

\subsection{Results of Analysis of Student Responses}

Based on the results of the questionnaire analysis of student responses one to one stage can be seen that the average results of all statements stated a positive answer of $66.7 \%$ while $33.3 \%$ of students stated a negative answer. While in the small group stage the positive answers were $66.7 \%$ and $21.2 \%$ stated negative answers. Student responses on field tests also showed more positive student responses than negative students' responses that were 72 , $3 \%$ and $27.3 \%$.

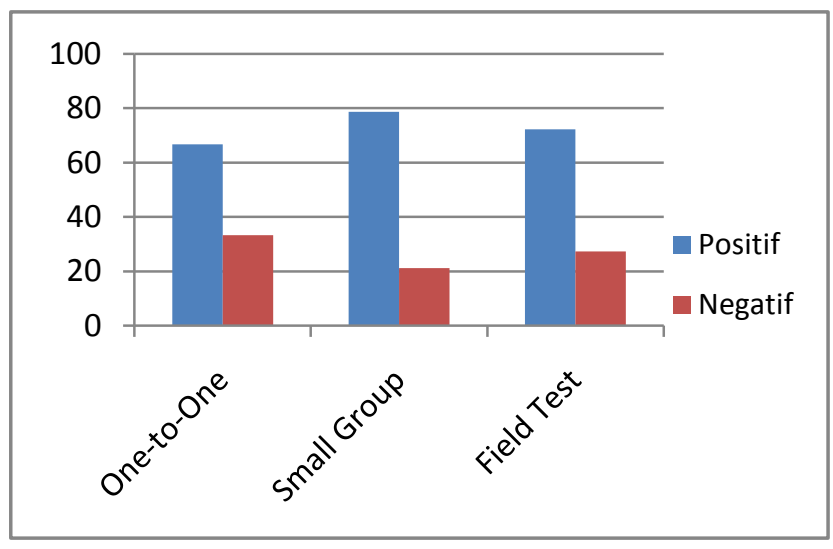

Figure 3. Analysis of Students Response of One to One, Small Group and Fiel Test

\subsection{Difficulty Level Analysis}

The following results of the analysis of the level of difficulty items about PISA mathematical problem-solving ability can be seen in Table 11 below:

Table 11. Difficulty Level Field Test Results

\begin{tabular}{ccc}
\hline Item & Difficulty level & Information \\
\hline 1 & 0.78 & Easy \\
2 & 0.56 & Medium \\
3 & 0.46 & Medium \\
4 & 0.26 & Hard \\
\hline
\end{tabular}

Based on Table 11 it is known that in the field test the difficulty level of problems numbers 1 are categorized as "Easy", number 2 and 3 are categorized as "Medium", number 4 are categorized as "Difficult". So that the problem based on the PISA level of mathematical problem-solving ability is stated to have a good level of difficulty because it has problems with easy and difficult categories.

\subsection{Distinguishing Power Analysis}

The results of the differentiation analysis of the items of the test instruments can be shown in Table 12. 
Table 12. Distinguishing Power of Field Test Results

\begin{tabular}{ccc}
\hline Item & Difficulty level & Information \\
\hline 1 & 0.29 & Enough \\
2 & 0.31 & Enough \\
3 & 0.31 & Enough \\
4 & 0.36 & Enough \\
\hline
\end{tabular}

Based on Table 12 it is known that in the field trial problems items 1,2,3,4 and 5 have the distinguishing power with the criteria of "Enough".

\subsection{Results of Item Reliability Tests}

This reliability test is based on the results of field trials involving field VIII-3 students of SMP Negeri 1 Padangsidimpuan. The total students in the class were 28 students. Students were asked to complete 5 problem descriptions in 2 x 40 minutes. Based on the results of the students' work it can be calculated the level of reliability test.

The instrument of reliability is used to determine the determination of test results. After calculating, the reliability of students' mathematical problem-solving ability was obtained as much as 0.651 (enough category). This shows that the test instrument was said to be reliable. So based on this analysis, there was no revision of the test instrument according to the reliability test.

\subsection{Student Mathematical Ability Test Results}

The results of the analysis of students' mathematical reasoning ability tests are shown in Table 13 below.

Table 13. Results of Analysis of Mathematical Reasoning Ability Tests

\begin{tabular}{cccccc}
\hline No & Student Score & Frequency & Percentage & Category & $\begin{array}{c}\text { Total } \\
\text { Student } \\
\text { Grade }\end{array}$ \\
\hline $\mathbf{1}$ & $80<$ Value $\leq 100$ & 0 & 0 & Excellent & \\
$\mathbf{2}$ & $60<$ Value $\leq 80$ & 3 & 10.71 & Good & \\
$\mathbf{3}$ & $40<$ Value $\leq 60$ & 22 & 78.58 & Enough & 1570 \\
$\mathbf{4}$ & $20<$ Value $\leq 40$ & 3 & 10.71 & Low & \\
$\mathbf{5}$ & $0<$ Value $\leq 20$ & 0 & 0 & Lowest & \\
\hline $\mathbf{\Sigma}$ & & 28 & 100 & & \\
\hline Average & 56.07 & &
\end{tabular}

Based on the analysis of instrument data to measure the mathematical problem solving ability of students it is known that from 28 field test subjects there were 3 students (10.71\%) which had mathematical problem-solving ability with good category, 22 students (78.58\%) which had mathematical problem-solving ability with enough category and 3 students (10.71\%) which had mathematical problem-solving ability with less category. So the average mathematical problem-solving ability test results obtained by students was 56.07 with enough category.

From the data, it can be concluded that the most dominating was a good category. For more details can be seen in the diagram presented in Figure 4 below.

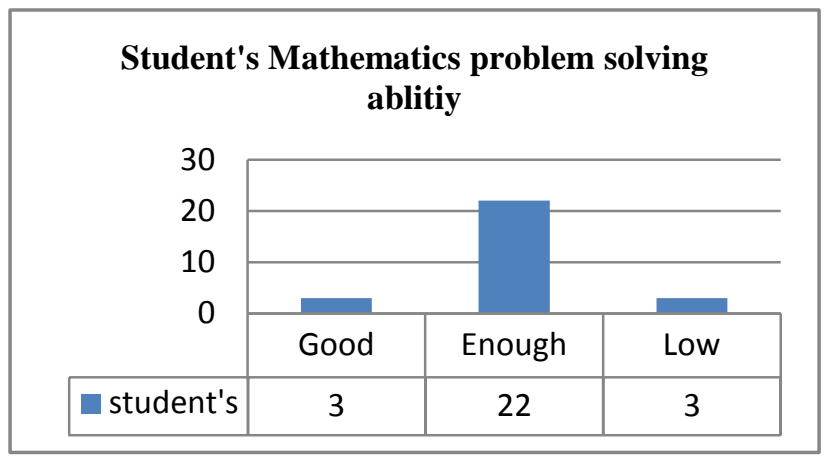

Figure 4. Results of Students' Mathematical Reasoning

Based on the results of the test validation the mathematical problems in space and shape content models were developed that, the components present in the test were declared valid with good category. The criteria of eligibility obtained through expert assessment of the test of the math problem mojnb del PISA space and shape content developed. Acquired a valid learning tool, caused by several factors, including: first, the tests developed have fulfilled the validity of the content. That is, in the development of tests the math problem model PISA space and shape content has been in accordance with the demands of the existing curriculum. The above is in line with the opinion of [36] stating that the validity of good content is if a learning device can measure certain specific objectives that align with the material or content of the given lesson. The validity of this content, often also referred to by the validity of the curriculum. Secondly, the test of the math problem model PISA space and shape content developed has fulfilled the validity of the construct. That is, in the development of tests of the math problem model PISA space and shape content, has been in accordance with the concepts and indicators of problem-solving ability. The results of the research and opinion, supported by the development research conducted by the son and [37] where the problem is declared valid in terms of content, construction, and language based on comments or expert advice and analysis results Quantitative in the validation test based on the results of the student response data analysis in the test field is obtained that, the average percentage of student responses in each trial is positive. This means that students respond positively to developed tests. This suggests that the test of the math problem model PISA space and shape content developed has fulfilled the effective criteria reviewed from the student's response.

In line with the research results, [38] problems developed have a number of potential effects, namely raising the involvement of various mathematical basic capabilities in the process of completion. In addition, it is also able to attract interest and motivate students so that they are challenged to solve problems. These problems also give the stimulus to the students to think critically using their own problem-solving in their completion. Based on the results of a posttest analysis of the mathematical problem-solving ability of students in the test field showed that students ' mathematical problemsolving ability is sufficient. This mathematical problemsolving ability is seen from the average posttest outcome of the concept of understanding the students have gained. This suggests that the use of the test of the mathematical problems of the PISA model content problem-solving 
ability of the students. The mathematical problem-solving ability above is influenced by the characteristics of the developed PISA mathematical problem test. Among them: First, the tests developed contain authentic problems relating to the daily life of students, clear, easy to understand and useful. Secondly, the activities are designed on the test according to the problem-solving indicators. Third, can create mathematical models of the tests given.

\section{Conclusion}

Based on the results of research and discussion of each stage of developing mathematical problem-solving ability test instruments, the results of validity and reliability analysis of students' mathematical problem-solving ability which had been developed were categorized as valid and reliable. This was obtained from the results of the analysis where the item tests were containing problem-based on PISA level were valid. The procedure for developing mathematical problem-solving test instruments for grade VIII-3 students of SMP Negeri 1 Padangsidimpuan through 4 stages, namely the preliminary stage, selfevaluation stage, the prototyping stage, and the field test stage. Students' mathematical problem-solving ability in working on problem-based on PISA level on cubes and beams was consist of 3 students (10.71\%) have mathematical problem-solving ability with good categories, 22 students (78.58\%) have mathematical problem-solving ability with enough categories. So, this research obtained an average of students' mathematical problem-solving ability was 56.07 which categorized as enough.

\section{Acknowledgments}

The researcher would like to thank Mrs. Lamsihar, S.Pd as a teacher of SMP Negeri 1 Padangsidimpuan, class VIII-3 students of SMP Negeri 1 Padangsidimpuan who participated in this research. Thank you to my parents who have supported me in writing this article.

\section{References}

[1] Edo, S.I., Ilma, R., \& Hartono, Y., "Investigating Secondary School Students' Difficulties in Modeling Problems PISA Model Level 5 And 6," IndoMS Journal on Mathematics Education (IndoMS - JME), 4 (01). 41-58. January. 2013.

[2] OECD, “PISA 2009 Results: Executive Summary,” New York: Columbia University. 2012.

[3] Saenz, Cesar, "The Role of Contextual, Conceptual and Procedural Knowledge in Activating Mathematical Competencies (PISA),” Madrid: Springer. 2008.

[4] Silva, Evy Yosita dkk. "Pengembangan Soal Matematika Model Pisa pada Konten Uncertainty untuk Mengukur Kemampuan Pemecahan Masalah Matematika Siswa Sekolah Menengah Pertama,” 2010. [Online] Avalaible: http://ejournal.unsri.ac.id/index.php/jpm/article/view.

[5] Riyanto, Wardono, dan Wijayanti, K., "Keefektivan PMRI Berbantuan Alat Peraga Terhadap Kemampuan Pemecahan Masalah Serupa PISA Pada Kelas VII,” Jurnal Kreano, Vol. 5 No. 1, 33-44. Juni. 2014

[6] Wardhani, Sri dan Rumiati., "Instrumen Penilaian Hasil Belajar Matematika SMP: Belajar dari PISA dan TIMSS," Pusat Pengembangan dan Pemberdayaan Pendidik dan Tenaga Kependidikan Matematika. Yogyakarta. 2011
[7] Kohar, A. W., Zulkardi, Z., \& Darmawijoyo, D., "Developing PISA-like mathematics task to promote student s" mathematical literacy," Proceedings of the 2nd SEA-DR (South East Asia Development Research) International Conference 2014 (SEADRIC 2014). Paris: Atlantis Press. 2014.

[8] Zulkardi dan Putri, R. I., "Mendesain Sendiri Soal Kontekstual Matematika," Prosiding in Konferensi Nasional Matematika ke 13. 1-7. Semarang. 2006.

[9] Kertayasa, I Ketut., “Indonesia PISA Center: Mathematics”. 2014 [online]. Avalaible. website for CBAM. http://www.indonesiapisacenter.com/2014/03/tentangwebsite.html. diakses tanggal 21-04-2019.

[10] Kohar, Ahmad Bachidul dan Zulkardi.,"Pengembangan Soal Berbasis Literasi Matematika dengan Menggunakan Kerangka PISA Tahun 2012”. Prosiding Konferensi Nasional Matematika XVII. Universitas ITS, Surabaya. 2014.

[11] Wardhani, Sri dan Rumiati., "Instrumen Penilaian Hasil Belajar Matematika SMP: Belajar dari PISA dan TIMSS," Pusat Pengembangan dan Pemberdayaan Pendidik dan Tenaga Kependidikan Matematika. Yogyakarta. 2011.

[12] Mardhiyanti, D., Putri, R. I. I., \& Kesumawati, N., "Pengembangan soal matematika model pisa untuk mengukur kemampuan komunikasi matematis siswa sekolah dasar,” Jurnal Pendidikan Matematika UNSRI, 5(1). 16-29. 2013.

[13] Kamaliyah, K., Zulkardi, Z., \& Darmawijoyo, D., "Developing the sixth level of PISA-like mathematics problems for secondary school students," Journal on Mathematics Education, 4(1). 9-28. January. 2014.

[14] Oktiningrum, W., Zulkardi, Z., \& Hartono, Y., "Developing PISAlike mathematics task with Indonesia natural and cultural heritage as context to assess students' mathematical literacy." Journal on Mathematics Education, 7(1). 1-8. January. 2016.

[15] OECD., "PISA 2012 Results: What Students Know and Can Do, Student Performance in Mathematics, Reading and Science (Volume 1)." Paris: OECD Publishing. 2013.

[16] Suwaji, Untung Trisna.,"Permasalahan Pembelajaran Geometri Ruang SMP dan Alternatif Pemecahannya.” Pusat Pengembangan Permeberdayaan Pendidik dan Tenaga Kependidikan Matematika. Yogyakarta: 2008.

[17] Halat, E., "Reform-Based Curriculum and Motivation in Geometry." Eurasia Journal of Mathematics, Science \& Technology Education, 4(3). 285-292. February. 2008.

[18] Wardhani, S., "Intrumen Penilaian Hasil Belajar Matematika SMP: Belajar dari PISA dan TIMSS,” Dirjen Peningkatan Mutu Pendidik dan Tenaga Kependidikan, P4TK, Jogyakarta. 2011..

[19] Wati, E. H., \& Murtiyasa, B., "Kesalahan Siswa Smp Dalam Menyelesaikan Soal Matematika Berbasis Pisa Pada Konten Change And Relationship." Prosiding Konferensi Nasional Penelitian Matematika dan Pembelajarannya (KNPMP I).UMS, 2502-6526. 2016

[20] Ojose, B., "Mathematics Literacy: Are we able to put the mathematics we learn into everyday use." Journal of Mathematics Education, 4(1). 89-100. June. 2011.

[21] OECD, "PISA 2015 Results: Excellence and Equity in Education (Volume 1).” Paris: OECD Publishing. 2016.

[22] Wardono., "The Realistic Learning Model With Character Education And PISA Assessment To Improve Mathematics Literacy.” International Journal of Education and Research, Vol. 2. No.7. July. 2014.

[23] Daulay, I.S., "Peningkatan Kemampuan Pemecahan Masalah Matematika dan Motivasi Belajar Siswa SMP Melalui model Pembelajaran Berbasis Masalah.” PARADIKMA. Medan. 2016.

[24] OECD., "PISA 2012 Results: What Students Know and Can Do, Student Performance in Mathematics, Reading and Science (Volume 1).” Paris: OECD Publishing. 2013.

[25] Nasution, S. U., Surya, E., \& Fauzi, A. M. Kms., "Differences Between Mathematical Problem-Solving Ability Of Students Taught Using Cooperative Learning Model Nht And Stad.” Jurnal IJARIIE, Vol-3 Issue-2. 2165-2169. February. 2017

[26] Ruseffendi, E. T.Dkk., “Pendidikan Matematika 3.” Jakarta: Depdikbud. 1991.

[27] OECD., "PISA 2015 Results: Excellence and Equity in Education (Volume 1).” Paris: OECD Publishing. 2016.

[28] OECD., "PISA 2012 Results in Focus: What 15-year-old know and what they can do with what they know." Paris: OECD Publishing. 2014. 
[29] Kohar, A., W., "Pengembangan Soal Matematika Model PISA Sebuah Alternatif Langkah Awal Memperbaiki Prestasi Literasi Matematika Siswa Indonesia.” 2014. [Online] Avalaible http://edukasi.kompasiana.com/

[30] Jurnaidi, J \& Zulkardi, Z., "Pengembangan Soal Model Pisa pada Konten Change and Relationship untuk Mengetahui Kemampuan Penalaran Matematis Siswa Sekolah Menengah Pertama. Jurnal Pendidikan Matematika, Vol. 8, No. 1. 25-42. Juli. 2013

[31] Tessmer, M., "Planning and conducting formative evaluations: Improving the quality of education and training.” London: Kogan Page. 1998

[32] Arikunto, S., “Prosedur Penelitian.” Rineka Cipta. Jakarta. 2009.

[33] Arikunto, S., “Dasar-dasar Evaluasi Pendidikan.” Bumi Aksara. Jakarta. 2012.
[34] Trianto., "Mendesain Model Pembelajaran Inovatif-Progresif." Prenada Media Group. Jakarta. 2010.

[35] Riduwan., “Belajar Mudah Penelitian.” Alfabeta. Bandung. 2011

[36] Arikunto, S., “Prosedur Penelitian.” Rineka Cipta. Jakarta. 2009.

[37] Lestari, N., Hartono, Y., \& Purwoko., "Pengaruh Pendekatan Open-Ended Terhadap Penalaran Matematika Siswa Sekolah Menengah Pertama Palembang.” Jurnal Pendidikan Matematika. 10 (1). 82-97. Januari. 2016.

[38] Charmila N, Zulkardi, Darmawijoyo., "Pengembangan Soal Matematika Model PISA Menggunakan Konteks Jambi.” Jurnal Penelitian dan Evaluasi Pendidikan. Vol. 20, No. 2.198-207. Desember. 2016.

(C) The Author(s) 2019. This article is an open access article distributed under the terms and conditions of the Creative Commons Attribution (CC BY) license (http://creativecommons.org/licenses/by/4.0/). 